\title{
Fogging low concentrated organic acid in a fattening pig unit - Effect on animal health and microclimate
}

\author{
Heiko Stein ${ }^{1}$, Jochen Schulz² ${ }^{2}$ Nicole Kemper², Alexander Tichy ${ }^{3}$, Ines Krauss ${ }^{1}$, Christian Knecht ${ }^{1}$, \\ Isabel Hennig-Pauka' \\ ${ }^{1}$ University Clinic for Swine, Department for Farm Animals and Veterinary Public Health, University of Veterinary \\ Medicine Vienna, Vienna, Austria \\ ${ }^{2}$ Institute for Animal Hygiene, Animal Welfare and Farm Animal Behaviour, University of Veterinary Medicine Hannover, \\ Foundation, Hannover, Germany \\ ${ }^{3}$ Department of Biomedical Sciences, University of Veterinary Medicine Vienna, Vienna, Austria
}

Stein H, Schulz J, Kemper N, Tichy A, Krauss I, Knecht Ch, Hennig-Pauka I. Fogging low concentrated organic acid in a fattening pig unit Effect on animal health and microclimate. Ann Agric Environ Med. 2016; 23(4): 581-586. doi: 10.5604/12321966.1226850

\section{Abstract}

Introduction and objective. In intensive pig production aerial contaminates are potential hazards for the health of animals and humans. In this study, the effect of fogging a low concentrated tartaric acid solution on pigs' health, environmental and hygiene parameters were evaluated in an inhabited fattening unit.

Materials and method. Pigs were housed in separate units (control group $n=109$ and experimental group $n=110$ ). During the whole fattening period, twice a week at 48 hour intervals, a $0.1 \%$ tartaric acid solution was aerosolized by a coldfogging system for 20 minutes in the experimental unit. Environmental parameters were spot-checked on days of fogging. Sedimentation dust and surfaces were analysed for bacterial and fungal load. Dust particle size distribution was assessed. Pigs were clinically examined weekly. Standard meat examination at an abattoir was extended by individual quantification of lung alterations.

Results. The fogging procedure had no influence on ammonia concentrations. A significant reduction of mould, but not of bacteria, was found in sedimentation dust, and bacterial and mould scores of surface samples were improved. A significant reduction of particle size classes 1.6-2.0 $\mu \mathrm{m}, 4.0-5.0 \mu \mathrm{m}, 7.5-10 \mu \mathrm{m}$, as well as 10-15 $\mu \mathrm{m}$ was observed. The high sound level of the fogging machine (82-102 dB) led to higher activity and pen-mate directed behaviour. More skin alterations, conjunctivitis and sneezing were recorded in the experimental group. Gross pathological lung alterations did not differ between both groups.

Conclusions. Although fogging of tartaric acid is limited to a concentration of $0.1 \%$ due to its irritating effect on the respiratory mucosa, reduction of microbial load can be achieved, but it would be enhanced by using more powerful fogging systems.

\section{Key words}

Fattening pigs, disinfection, fogging, tartaric acid, dust, ammonia

\section{INTRODUCTION}

Respiratory diseases in swine are still of concern for productivity, animal welfare and consumer protection, although effective vaccines against the most important pathogens are available. Percentages of lung alterations found at slaughter are high and respiratory disease is the main reason for antibiotic usage in this species $[1,2]$. The synergistic effects of infectious agents and environmental factors as dust and hazardous gases have been known for a long time, but awareness for their impact is relatively new $[3,4]$. Under the socio-medical pressure to reduce antibiotic usage in livestock as much as possible, at present the focus of veterinary advisory on farms is to obtain animal health and productivity in coexistence with pathogenic microorganisms. The precondition is the reduction of environmental factors known to interact with anatomical structures in the respiratory tract, e.g. dust and ammonia.

Address for correspondence: Isabel Hennig-Pauka, University Clinic for Swine, Department for Farm Animals and Veterinary Public Health, University of Veterinary Medicine Vienna, Veterinärplatz 1, 1210 Vienna, Austria

E-mail: Isabel.Hennig-Pauka@vetmeduni.ac.at

Received: 09 October 2015; accepted: 17 May 2016
An adverse effect of dust on the phagocytic activity of macrophages as important effector cells of innate immunity has been shown. In exposed pigs, an increased expression of CD163 as an important receptor for Porcine Reproductive and Respiratory Virus (PRRSV) on macrophages has also been found, so that virus entry was facilitated [5]. Dust also enhances infections, agglutination and hypertrophy of cilia [6]. Aerial contaminates in confinement swine buildings were not only found to impair the pigs health status, but were a potential hazard for farm workers and veterinarians, and are therefore an important issue for medical agencies and insurances involved in the evaluation of working place safety $[7,8]$. In humans, repeated dust exposure lead to chronic obstructive pulmonary disease with the consequence of impaired respiratory function parameters [9].

Dust in swine confinements is composed of feed, skin, faeces particles and airborne microorganisms, which were found to be approximately $80 \%$ staphylococci and streptococci, 1\% fungi, yeasts and moulds and $0.5 \%$ enterobacteriacea of the total aerobic microorganisms $[10$, $11,12]$. An important zoonotic bacteria associated with dust particles is Streptococcus suis causing disease in farm workers with increasing incidences $[13,14]$. Livestock- associated 
methicillin-resistant Staphylococcus aureus (MRSA) are highly prevalent on many farms and can be emitted into the environment by forced ventilation systems [15]. Residues of antimicrobial substances in dust, which originate from oral treatments in swine groups, are an important factor for the development of bacterial resistances against antimicrobials [16].

Next to dust, the most important gaseous hazard is ammonia, which accumulates in the air depending on the slurry system, floor design and air circulation [17]. While upper tolerable limits in swine husbandry is considered to be 20 ppm [18], Hamilton et al., found that a continuous lower concentration of $5 \mathrm{ppm}$ aggravates the development of turbinate atrophy induced by Pasteurella multocida [19]. As Jones et al. describe, free ranging pigs avoid compartments with measurable ammonia concentrations and move to rooms with fresh air [20]. About $40 \%$ of total ammonia can be absorbed to dust particles, but under practical conditions only the gaseous form of ammonia is measured. The health hazard due to ammonia absorbed to respirable dust particles and solubilised directly in the epithelial lining fluid covering the airway, can momentarily not be assessed [21, 22].

Fogging procedures in swine confinements are practical approaches to reduce air contamination. Dust reduction in stables can be achieved by oil fogging [23], while fogging with disinfectants is more common in the food industry and hospitals $[24,25,26]$. To the best of the authors' knowledge, only one study about fogging with a disinfectant in an inhabited pig unit has been published [27]. In that study, fogging with a combinatory product with peroxide and anionic detergent in a farrowing and rearing unit, resulted in a reduction of ammonia, dust particles and fungal spores.

\section{OBJECTIVES}

In the presented study, the effects of fogging with a newly developed, low concentration of tartaric acid solution using a prototype of a portable cold-fogging system were evaluated in an inhabited fattening unit. Tartaric acid is an admitted and widely-used food additive in the European Union and can be used also for cleaning in livestock farming. This flexible approach might be more eligible in common farming practices as well as on small farms.

\section{MATERIALS AND METHOD}

Animals and housing. The trial was carried out on the farrow-to-finishing farm of the University of Veterinary Medicine, Vienna, in Lower Austria. Two identical adjacent fattening units with an air volume of $617 \mathrm{~m}^{2}$, partly slatted floor and 10 pens each were used in the experiment. 109 (control unit) and 110 pigs 10-13-weeks-old (experimental unit) were individually marked with ear tags, weighed, and randomly assigned to both groups after units had been thoroughly cleaned and disinfected. Pigs were fed automatically 4 times per day with pelleted feed, and had free access to drinking water.

Fogging procedure. A solution containing $0.1 \%$ tartaric acid as the active component $(0.5 \%$ CV 004 A, ConVet $\mathrm{GmbH} \&$ Co. KG, Monheim, Germany) was fogged in the experimental unit two times a week with a 48 hours interval until slaughter. A prototype of a portable cold-fogging system (UNIPRO ${ }^{2}$, IGEBA, Weitennau, Germany) positioned in the middle of the corridor was used to aerosolize $4500 \mathrm{ml}$ of the solution within 20 minutes using a pressure of 0.2 bar. During fogging procedure the forced ventilation system was turned off.

Environmental parameters. At one day per week specific environmental parameters were spot-checked before and after the ventilation was deactivated in both units. In the centre of each pen and at 3 locations in the corridor at a height of $50 \mathrm{~cm}$ above the floor, the relative humidity $(\mathrm{RH})$, air temperature, air velocity and concentration of carbon dioxide $\left(\mathrm{CO}_{2}\right)$ were measured by a portable analyser (TESTO 400, Testo AG, Lenzkirch, Germany) with accuracies for $\mathrm{RH}$ of $\pm 2 \%$, temperature $- \pm 0.4^{\circ} \mathrm{C}$, air velocity $- \pm 0.03 \mathrm{~m} / \mathrm{s}$ and $\mathrm{CO}_{2}$ concentration - $\pm 50 \mathrm{ppm}$, according to the manufacturer's specifications. Ammonia concentration was measured with a single gas detector (ToxiVision Biosystems, Sperian Instrumentation, Middletown, USA) with an accuracy of 1 ppm.

On one occasion, the sound level was measured before and during fogging in each pen and in 3 locations in the corridor, using a mobile sound level meter (MODEL 93-20, Greenlee Textron Inc., Rockford, USA).

Dust measurement. Sedimentation dust was collected within 2 subsequent time periods of 4 and 6 weeks. 6 boards $\left(0.35 \times 0.7 \mathrm{~m}^{2}\right)$ covered with autoclaved aluminium foil were fixed in each compartment at a height of $1.90 \mathrm{~m}$, and dust was harvested by brushing the foils surfaces after weighing them.

Air dust particle size distribution was determined for a period of 11 days simultaneously in both compartments. A portable dust collector (Portable Dust Monitor, Series 1.100 of Grimm Aerosol Technik GmbH \& Co. KG, Ainring, Germany) was positioned in the middle of the corridor at a height of $50 \mathrm{~cm}$. Within 1 hour, 72 litres of air was filtered and 15 particle size classes in the range of $<0.3 \mu \mathrm{m}$ to $<20 \mu \mathrm{m}$ were recorded cumulatively at 10 minute intervals.

Microbiological examination. $100 \mathrm{mg}$ sedimentation dust was solubilised in $10 \mathrm{ml}$ PBS containing $0.01 \%$ Tween 20 , heated for 30 minutes at $25^{\circ} \mathrm{C}$ in a water bath, centrifuged at $120 \mathrm{rpm}$, followed by vortexing for 5 minutes at $2400 \mathrm{rpm}$. Total bacterial cell counts were determined from $100 \mu \mathrm{l}$ of serial dilutions on blood agar plates (Oxoid Ltd., Hampshire, UK) and streptococci on azide blood agar base (Oxoid Ltd., Hampshire, UK) according to Schulz et al. [28]. For determination of MRSA, $0.5 \mathrm{~g}$ sedimentation dust was solubilised in $50 \mathrm{ml}$ PBS containing $0.01 \%$ Tween 20 , and bacterial cultures performed according to Friese et al. [29]. Mould was quantified by plating out $0.5 \mathrm{ml}$ aliquots of dust solutions, as described by Schulz et al. [28].

On 3 occasions, at the beginning, middle and end of the pig fattening period, contact plate samples (PCA Contact TLHTh triple wrap VWR International GmbH, Radnor USA) were collected in 10 predefined locations (sites) in each group for semiquantitative microbiological diagnostics. For group comparison, a total of 30 contact plates per group were evaluated. In the experimental unit, the 10 contact plate samples were taken approximately 10 minutes before, and additionally 10 contact plate samples were taken after fogging. 
According to the technical data sheet of the agar contact plates and described by Huneau-Salaün et al. [30], plates were incubated for 48 hours at $37^{\circ} \mathrm{C}$ under aerobic conditions and evaluated by eye, according to a modified scoring scheme routinely used to evaluate poultry hygiene protocols in Belgium, within vertically integrated entities [31].

After 48 hours of incubation time, single bacterial colonies were counted on the contact agar plates according to the Belgian protocol. If no bacterial growth was observed, the bacterial score was zero. 1-40 colonies were classified as score 1, 41-120 colonies as score 2, 121-400 colonies as score 3 , more than 400 colonies as score 4 , and uncountable numbers of colonies due to confluent growth were classified as score 5. Moulds were quantified using a mould score with score 0 - when no moulds were grown, score 1 - when mould colonies in total covered up to a quarter of the agar surface, score 2 - when mould colonies covered more than a quarter but not more than the half of the agar plate, and score 3 - when mould colonies covered in total more than the half of the agar plate. The bacterial and mould scores from all contact plate samples used (30 plates per group in total) were compared between the groups with the MannWhitney-U-Test. In addition, the bacterial and mould scores before and after the fogging procedure were compared by the Wilcoxon signed ranks test.

Clinical examination and slaughter check. Once a week, after fogging, pigs were clinically examined. Sneezes and coughs were counted for 3 minutes and divided by the number of animals observed, according of the scheme of Nathues et al. [32]. Frequencies of skin lesions, conjunctivitis, lameness and diarrhoea were recorded per pen. In the experimental group, the coughing and sneezing indices were also recorded before fogging.

At the end of the fattening period, the pigs were weighed and transported for slaughtering. Lungs were assigned to the individual pigs and thoroughly examined for gross pathological findings with scores between $0-4$ for pneumonia and pleurisy per lung lobe, according to the scheme of Madec and Kobisch [33].

Statistical analysis. Statistical analysis was performed using IBM ${ }^{*}$ SPSS ${ }^{*}$ Statistics Version 20.0 (IBM Corp., Armonk, NY, USA). Aggregated data related to 10 animals were generated from clinical findings. Dust particle size values measured during fogging were excluded from evaluation. Data were verified for normal distribution using Kolmogorow-SmirnowTest. Quantitative data with normal distribution were evaluated using repeated measures ANOVA (comparison of environmental parameters between groups) or Student's t-test (parameters in sedimentation dust, dust particles in the air, average daily weight gain and clinical findings). Cough and sneeze indexes, as well as environmental parameters prior to and after the fogging procedure, were compared using Student's paired samples t- test. Data with no normal distribution were evaluated using Mann-Whitney-U-Test (lung scores, bacterial and mould scores). The bacterial and mould scores prior to and after the fogging procedure were compared by the Wilcoxon signed ranks test. The significance level was set at $(\mathrm{p}<0.05)$.

The study was approved by the institutional Ethics Committee in accordance with Good Scientific Practice guidelines and national legislation.

\section{RESULTS}

Environmental parameters. One day per week, environmental parameters were measured in each group before deactivation of ventilation and after the time period of fogging in 13 different stable locations, when ventilation was deactivated. All environmental parameters differed significantly between the two times of measurements within the groups, with the exception of temperature in the experimental group (Tab. 1). Differences between the groups were analysed by ANOVA for repeated measurements. Significantly higher relative humidity $(\mathrm{p}<0.001)$ and $\mathrm{CO}_{2}$ concentration $(\mathrm{p}=0.004)$ were found in the experimental group, while air temperature was lower $(\mathrm{p}<0.001)$ compared to the control group. Noise measurements resulted in sound volume changes from background noises of $60-70 \mathrm{~dB}$ to $82-102 \mathrm{~dB}$ during the fogging procedure. A sound volume of $102 \mathrm{~dB}$ was measured next to the running fogging machine in the middle of the corridor between the pens.

Dust analysis. The results of sedimentation dust analysis are shown in Table 2. No significant differences in total amounts, bacterial load, streptococci and MRSA were found between the two units. Moulds were reduced significantly by the fogging procedure $(\mathrm{p}=0.022)$.

The mean total average dust particle concentration measured per day in the air did not differ between groups (control group: $1.93 \times 10^{5} / 1$, experimental group: $1.73 \times 10^{5} / 1$ ), while inhalable particle size classes $1.6-2.0 \mu \mathrm{m}$ and $4.0-$ $5.0 \mu \mathrm{m}$, as well as $7.5-10.0 \mu \mathrm{m}$ and $10-15 \mu \mathrm{m}$ were decreased in the experimental group (Fig.1).

Assessment of disinfectant effects of fogging. Semiquantitative microbiological findings prior to and after fogging in the experimental group compared to the control group are shown in Table 3. A significant reduction of the bacterial scores $(p=0.002)$ and the mould scores $(p=0.035)$ were found in the experimental group compared to the control group. A significant reduction in these hygiene scores was recorded after fogging (bacterial score $\mathrm{p}=0.013$; mould score $\mathrm{p}=0.034$ ).

Clinical examination and lung health status. The mean average daily weight gain in pigs of the control group (mean and standard deviation: $904.8 \mathrm{~g} \pm 106.4 \mathrm{~g}$ ) did not differ significantly from those of the experimental group (mean and standard deviation: $883.2 \mathrm{~g} \pm 119.8 \mathrm{~g}$ ).

Results of clinical examinations in the experimental group revealed significantly more skin alterations, diarrhoea and conjunctivitis than in the control group (Tab. 4). Significantly more pigs sneezed after fogging compared to prior to fogging $(\mathrm{p}=0.046)$.

Neither lung lesion scores nor frequencies of lungs with gross pathological findings differed between the 2 groups. The median lung scores were 0 in both groups. Overall $69 \%$ of the assessed lungs were unaffected and 31\% slightly affected. 
Table 1. Environmental parameters in the fattening units

\begin{tabular}{|c|c|c|c|c|c|c|c|c|}
\hline & & \multicolumn{3}{|c|}{$\begin{array}{c}\text { Before fogging/ } \\
\text { before deactivation of } \\
\text { ventilation }\end{array}$} & \multicolumn{3}{|c|}{$\begin{array}{l}\text { After fogging, } \\
\text { ventilation still } \\
\text { deactivated }\end{array}$} & \multirow[b]{2}{*}{$p$-value } \\
\hline & & Min. & Max. & Mean $\pm S D$ & Min. & Max. & Mean $\pm S D$ & \\
\hline \multirow{5}{*}{$\begin{array}{l}\text { Control } \\
\text { group } \\
\text { (no } \\
\text { fogg- } \\
\text { ing) }\end{array}$} & $\mathrm{T}\left({ }^{\circ} \mathrm{C}\right)$ & 17.1 & 24.9 & $20.0 \pm 1.2$ & 15.4 & 23.6 & $21.2 \pm 1.5$ & $<0.001$ \\
\hline & R.H. \% & 54 & 82 & $68 \pm 6$ & 53 & 88 & $74 \pm 6$ & $<0.001$ \\
\hline & $\begin{array}{c}\text { air } \\
\text { velocity } \\
{[\mathrm{m} / \mathrm{s}]}\end{array}$ & 0 & 0.42 & $0.14 \pm 0.06$ & 0 & 0.32 & $0.12 \pm 0.05$ & 0.048 \\
\hline & $\begin{array}{c}\mathrm{CO}_{2} \\
{[\mathrm{ppm}]}\end{array}$ & 1209 & 3013 & $2097 \pm 374$ & 260 & 5838 & $3001 \pm 917$ & $<0.001$ \\
\hline & $\begin{array}{c}\mathrm{NH}_{3} \\
\text { [ppm] }\end{array}$ & 0 & 18 & $8 \pm 4$ & 0 & 28 & $12 \pm 6$ & $<0.001$ \\
\hline \multirow{5}{*}{$\begin{array}{l}\text { Experi- } \\
\text { mental } \\
\text { group } \\
\text { (fogg- } \\
\text { ing) }\end{array}$} & $\mathrm{T}\left(\mathrm{C}^{\circ}\right)$ & 18.0 & 21.50 & $19.9 \pm 1.0$ & 13.0 & 23.0 & $19.9 \pm 5.9$ & 0.927 \\
\hline & R.H. \% & 49 & 79 & $68 \pm 6$ & 73 & 98 & $86 \pm 5$ & $<0.001$ \\
\hline & $\begin{array}{c}\text { air } \\
\text { velocity } \\
{[\mathrm{m} / \mathrm{s}]}\end{array}$ & 0 & 0.32 & $0.15 \pm 0.05$ & 0 & 0.37 & $0.12 \pm 0.06$ & $<0.001$ \\
\hline & $\begin{array}{c}\mathrm{CO}_{2} \\
{[\mathrm{ppm}]}\end{array}$ & 1442 & 2893 & $2129 \pm 395$ & 2266 & 4653 & $3283 \pm 669$ & $<0.001$ \\
\hline & $\begin{array}{c}\mathrm{NH}_{3} \\
{[\mathrm{ppm}]}\end{array}$ & 0 & 19 & $9 \pm 5$ & 0 & 25 & $12 \pm 6$ & $<0.001$ \\
\hline
\end{tabular}

Significant differences before deactivation of ventilation/fogging and after were calculated by Student's paired samples t-test within the groups. Data analysis by repeated measures ANOVA revealed significant differences $(p<0.01)$ in temperature $(T)$, relative air humidity (R.H.) and $\mathrm{CO}_{2}$-concentration between control group and experimental group. $\mathrm{Min}^{2}$-concentration between control group and experimental

Table 2. Analysis of sedimentation dust in control and experimental groups

\begin{tabular}{llccc} 
& & Min. & Max. & Mean \pm SD \\
\hline \multirow{4}{*}{$\begin{array}{l}\text { Control } \\
\text { group }\end{array}$} & Sedimentation dust [g/m²/d] & 1.41 & 3.77 & $2.53 \pm 0.72$ \\
\cline { 2 - 5 } & Total bacteria [CFU/g dust] & $7.9 \times 10^{7}$ & $4.8 \times 10^{8}$ & $2.6 \times 10^{8} \pm 9.7 \times 10^{7}$ \\
\cline { 2 - 5 } & Streptococci [CFU/g dust] & $7.9 \times 10^{6}$ & $6.9 \times 10^{7}$ & $3.1 \times 10^{7} \pm 2.1 \times 10^{7}$ \\
\cline { 2 - 5 } & MRSA [CFU/g dust] & 0 & $1.7 \times 10^{4}$ & $3.9 \times 10^{3} \pm 4.5 \times 10^{3}$ \\
\cline { 2 - 5 } & Mould [CFU/g dust] & $1.0 \times 10^{4}$ & $1.6 \times 10^{5}$ & $3.8 \times 10^{4} \pm 3.9 \times 10^{4}$ \\
\hline \multirow{3}{*}{$\begin{array}{l}\text { Experi- } \\
\text { mental } \\
\text { group }\end{array}$} & Sedimentation dust [g/m2/d] & 1.4 & 3.81 & $2.55 \pm 0.73$ \\
\cline { 2 - 5 } & Total bacteria [CFU/g dust] & $9.4 \times 10^{7}$ & $8.5 \times 10^{8}$ & $2.5 \times 10^{8} \pm 2.0 \times 10^{8}$ \\
\cline { 2 - 5 } & Streptococci [CFU/g dust] & $4.4 \times 10^{6}$ & $4.5 \times 10^{7}$ & $2.0 \times 10^{7} \pm 1.3 \times 10^{7}$ \\
\cline { 2 - 5 } & MRSA [CFU/g dust] & 0 & $1.3 \times 10^{4}$ & $3.1 \times 10^{3} \pm 4.4 \times 10^{3}$ \\
\cline { 2 - 5 } & Mould [CFU/g dust] & $2.9 \times 10^{3}$ & $2.1 \times 10^{4}$ & $9.6 \times 10^{3} \pm 4.9 \times 10^{3}$ \\
\hline
\end{tabular}

G - gram; $\mathrm{m}$ - meter; $\mathrm{d}$ - day; CFU - colony forming units; MRSA - Methicillin resistant Staphylococcus aureus

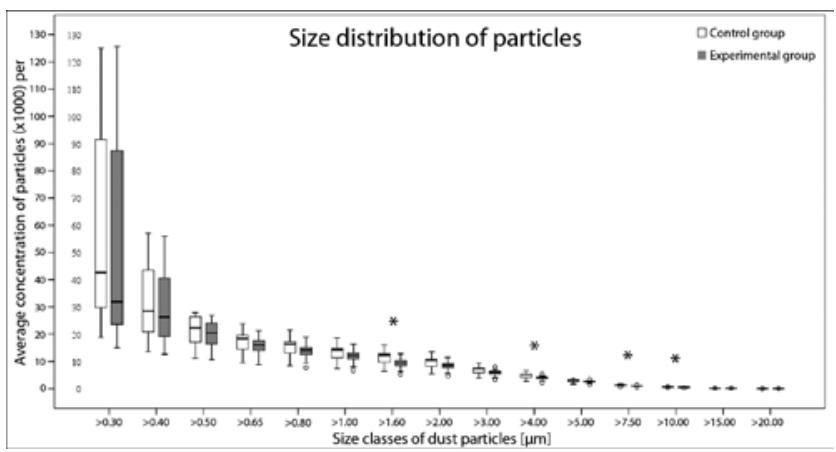

Figure 1. Dust particle size distribution. Comparison of different dust particle size classes measured during a period of 11 days in the control and experimental group. * Significant differences between the two groups $(p<0.05)$
Table 3. Hygiene bacterial and mould scores determined at different stable localisations at the beginning, middle and end of fattening period

\begin{tabular}{|c|c|c|c|c|c|c|c|}
\hline \multirow[b]{2}{*}{ CFU/plate } & \multirow[b]{2}{*}{$\begin{array}{c}\text { Bacterial } \\
\text { colony } \\
\text { count score }\end{array}$} & \multicolumn{2}{|c|}{ Control group } & \multicolumn{2}{|c|}{$\begin{array}{l}\text { Experimental } \\
\text { group before } \\
\text { fogging }\end{array}$} & \multicolumn{2}{|c|}{$\begin{array}{c}\text { Experimenta } \\
\text { group after } \\
\text { fogging }\end{array}$} \\
\hline & & $\begin{array}{l}\text { No. of } \\
\text { plates }\end{array}$ & $\%$ & $\begin{array}{l}\text { No. of } \\
\text { plates }\end{array}$ & $\%$ & $\begin{array}{l}\text { No. of } \\
\text { plates }\end{array}$ & $\%$ \\
\hline 0 & 0 & 0 & 0 & 0 & 0 & 0 & 0 \\
\hline $1-40$ & 1 & 0 & 0 & 0 & 0 & 0 & 0 \\
\hline $41-120$ & 2 & 0 & 0 & 0 & 0 & 0 & 0 \\
\hline $121-400$ & 3 & 0 & 0 & 3 & 10 & 4 & 13.3 \\
\hline$>400$ & 4 & 5 & 16.7 & 13 & 43.3 & 20 & 66.7 \\
\hline uncountable & 5 & 25 & 83.3 & 14 & 46.7 & 6 & 20.0 \\
\hline Total & & 30 & 100 & 30 & 100 & 30 & 100 \\
\hline \multirow[t]{2}{*}{ Median score } & & 5 & & 4 & & 4 & \\
\hline & $\begin{array}{l}\text { Mould- } \\
\text { Score }\end{array}$ & $\begin{array}{l}\text { No. of } \\
\text { plates }\end{array}$ & $\%$ & $\begin{array}{l}\text { No. of } \\
\text { plates }\end{array}$ & $\%$ & $\begin{array}{l}\text { No. of } \\
\text { plates }\end{array}$ & $\%$ \\
\hline No Mould & 0 & 13 & 43.3 & 20 & 66.7 & 25 & 83.3 \\
\hline Mild, sporadic & 1 & 11 & 36.7 & 9 & 30 & 5 & 16.7 \\
\hline Moderate & 2 & 5 & 16.7 & 1 & 3.3 & 0 & 0 \\
\hline High-grade & 3 & 1 & 3.3 & 0 & 0 & 0 & 0 \\
\hline Total & & 30 & 100 & 30 & 100 & 30 & 100 \\
\hline Median score & & 1 & & 0 & & 0 & \\
\hline
\end{tabular}

Table 4. Clinical findings in control and experimental groups recorded in 16 examinations days

\begin{tabular}{lccccccc}
\hline & \multicolumn{3}{c}{ Control group } & \multicolumn{5}{c}{ Experimental group } \\
\hline & Min. & Max. & Mean \pm SD & Min. & Max. & Mean $\pm S D$ & $p$-value \\
\hline Sneeze Index & 0 & 0.24 & $0.03 \pm 0.05$ & 0 & 0.15 & $0.02 \pm 0.04$ & 0.65 \\
\hline Cough Index & 0 & 0.12 & $0 \pm 0.02$ & 0 & 0.55 & $0.02 \pm 0.07$ & 0.06 \\
\hline $\begin{array}{l}\text { General skin } \\
\text { lesions }\end{array}$ & 0 & 7.27 & $3.26 \pm 1.50$ & 0 & 9.09 & $4.71 \pm 2.14$ & $<0.001$ \\
\hline Ear lesions & 0 & 6.36 & $2.30 \pm 1.61$ & 0 & 10.00 & $4.46 \pm 2.55$ & $<0.001$ \\
\hline Tail lesions & 0 & 1.82 & $0.09 \pm 0.29$ & 0 & 3.00 & $0.33 \pm 0.65$ & $<0.001$ \\
\hline Conjunctivitis & 0 & 8.18 & $2.93 \pm 1.90$ & 0 & 9.09 & $3.62 \pm 1.95$ & 0.004 \\
\hline Lameness & 0 & 2.73 & $0.31 \pm 0.65$ & 0 & 3.08 & $0.35 \pm 0.59$ & 0.571 \\
\hline Diarrhoea & 0 & 0 & 0 & 0 & 4.00 & $0.17 \pm 0.52$ & $<0.001$ \\
\hline
\end{tabular}

\section{DISCUSSION}

The approach in this project to improve air quality and hygiene in an occupied fattening unit was fogging of an innovative tartaric acid formulation as a non-hazardous high potential cleaning agent, which is able to kill microorganisms and destroy their genetic information (DNA, RNA). A 20-minute deactivation of ventilation during fogging might not have been adequate for a homogenous dispersion of the cleaning agent, but could not be extended due to the limited machine power. Carbon dioxide concentrations accumulated beyond the recommended threshold of $3000 \mathrm{ppm}$ [18] during this time period. Although fogging time was short, a higher relative humidity and a compensation of a temperature increase during ventilation deactivation was achieved, which was comparable to the results of Haeussermann [34] et al. using water-fogging against heat stress. In contrast to the study of Costa et al. [27] where fogging was applied once per day 
for 15 minutes, ammonia concentrations were not reduced. The significantly higher carbon dioxide concentration in the experimental group comparing with the control group might be due to higher activity of pigs which were irritated by the increased sound volume from the background noise of $60-64 \mathrm{~dB}$ to $82-86 \mathrm{~dB}$ during fogging. Carbon dioxide exhalation can be doubled in active compared to resting pigs [35]. Repeated noise must be considered as an environmental stressor for pigs with measurable effects on the hypothalamic-pituitary-adrenocortical axis [36], leading to increased pen-mate-directed aggressions. Significantly higher prevalence of skin alterations and also diarrhoea in the experimental group compared with the control group might be related to the additional 2-weekly stress factor. With approximately $2.5 \mathrm{~g} / \mathrm{m}^{2}$ per day, the amount of sedimentation dust was higher than the $0.93 \mathrm{~g} / \mathrm{m}^{2}$ per day measured in the study of Saleh [37] who took samples from rearing piglets. Air dust particle size distribution was comparable with those in the study of Lai et al. [38]. Specific dust particle fractions were reduced by fogging, reflecting the expected effect of a quicker sedimentation of agglomerated enlarged dust particles due to higher air humidity. Similar to the effect of citric acid fogging [26], a significant mould reduction was achieved. Total bacterial load as well as streptococci and MRSA were non-significantly decreased in dust in the experimental group, while the microbiological hygienic score for the assessment of surface contamination was significantly lower. This discrepancy might be due to the obvious shorttime effect of the disinfectant, which became visible by the reduced hygienic scores directly after fogging, while a longtime effect onto sedimentation dust which had accumulated over a period of time of 4-6 weeks was not observed. The reduction in specific particle size classes can be assessed as a medium time-effect. The size of mould spores was in the range of the reduced particle sizes between 7.5-15 $\mu \mathrm{m}$. The exposition to mould spores is a risk factor for the development of allergic diseases in human [39]. Further developments in this approach of air cleaning by fogging, but also by air filtration methods, could promote occupational health in swine workers.

To the best of the authors' knowledge, no studies about the disinfectant effects of fogged tartaric acid in swine husbandry have been performed previously. Tartaric acid has been used successfully for litter disinfection in broiler housings in concentrations of $4 \%$, resulting in a reduction of microbial load by approximately $10^{3} \mathrm{CFU} / \mathrm{g}$ [40]. Fogging with tartaric acid in the presence of living animals is limited to a concentration of $0.1 \%$, because higher concentrations lead to non-tolerable irritations of the respiratory tract. Irritations of the respiratory tract in pigs exposed to tartaric acid aerosols with higher concentrations had been observed during preliminary fogging tests before the start of the study. In humans exposed to tartaric acid, the cough threshold was reached already at $0.12 \%$, which is comparable to the concentration used in this study [41]. While only the sneeze index but not the cough index increased after fogging, it can be assumed that tartaric acid mainly affects the upper airways and the conjunctivae. Nevertheless, the respiratory health status of all pigs was assessed as good. In contrast to this, immediate coughing in pigs was provoked by $0.025-0.8$ molar citric acid fogging [42].

A concentration of $1.5 \%$ CV004 A is recommended by the manufacturer for surface cleaning. In this concentration, a bactericidal effect of the product has been proved in vitro. Additional cleaning of surfaces using this higher concentrated solution might support the cleaning effect of fogging, because sedimentation dust will be disinfected before being swirled again and the number of microorganisms will be reduced in dust from surfaces which can become airborne.

\section{CONCLUSION}

Tartaric acid as a harmless disinfectant can reduce the microbial load in occupied stables of pigs. The high sound volume produced by the portable cold fogging device was very likely a stress factor for the pigs. For future applications, alternative fogging-systems operated with higher frequency, and even with lower ventilation rates, could be more effective concerning the microbial reduction. The significant reduction of inhalable dust particles and moulds may contribute to the improvement of health conditions for farm workers and veterinarians.

\section{Acknowledgements}

The authors would like to thank Dr. Olaf Hansen, ConVet GmbH\&Co.KG, Monheim, Germany for providing the cleaning agent, and Alberto Sabatini, IGEBA GmbH, Weitenau, Germany for the portable cold-fogging system.

\section{REFERENCES}

1. Steinmann T, Blaha T, Meemken D. A simplified evaluation system of surface-related lung lesions of pigs for official meat inspection under industrial slaughter conditions in Germany. BMC Vet Res. 2014; 10(98): $1-12$.

2. Pagot E, Pommier P, Keïta A. Relationship between growth during the fattening period and lung lesions at slaughter in swine. Rev Med Vet Toulouse. 2007; 158(5): 253-259.

3. Wathes C M, Deminers T G M, Teer N, White R P, Taylor L L, Bland $\mathrm{V}$, et al. Production responses of weaned pigs after chronic exposure to airborne dust and ammonia. Anim Sci. 2004; 78(1): 87-97.

4. Murphy T, Cargill C, Rutley D, Stott P. Pig-shed air polluted by a-haemolytic cocci and ammonia causes subclinical disease and production losses. Vet Rec. 2012; 171(5): 123-123.

5. Knetter S M, Tuggle C K, Wannemuehler M J, Ramer-Tait A E. Organic barn dust extract exposure impairs porcine macrophage function in vitro: implications for respiratory health. Vet Immunol Immunop. 2014; 157(1-2): 20-30.

6. Jassmann H, Johannsen U, Liebmann K, Mehlhorn G. Pathomorphological investigations on effects of stable dust to the respiratory tract of piglets without and with experimental pasteurella multocida infection. Proceedings of the 12th International Pig Veterinary Society Congress; 1992 Aug 17- 20; Den Haag,Netherlands. Boxtel: The Committee; 1992.

7. Radon K, Danuser B, Iversen M, Jörres R, Monso E, Opravil U, et al. Respiratory symptoms in European animal farmers. Eur Respir J. 2001; 17(4): 747-754.

8. Andersen C I, Von Essen S G, Smith L M, Spencer J, Jolie R, Donham K J. Respiratory symptoms and airway obstruction in swine veterinarians: a persistent problem. Am J Ind Med. 2004; 46(4): 386-392.

9. Monsó E, Riu E, Radon K, Magarolas R, Danuser B, Iversen M, et al. Chronic obstructive pulmonary disease in never-smoking animal farmers working inside confinement buildings. Am J Ind Med. 2004; 46(4): 357-362.

10. Seedorf J, Hartung J. Stäube und Mikroorganismen in der Tierhaltung. 1st ed. Münster (DE) KTBL-Schrift 393, 2002.

11. Hartung J, Saleh M. Composition of dust and effects on animals. Landbauforschung Voelkenrode. 2007; Special Issue 308: 111-116.

12. Kristiansen A, Saunders A M, Hansen A A, Nielsen P H, Nielsen J L. Community structure of bacteria and fungi in aerosols of a pig confinement building. FEMS Microbiol Ecol. 2012; 80(2): 390-401. 
13. Gottschalk M, Segura M, Xu J. Streptococcus suis infections in humans: the Chinese experience and the situation in North America. Anim Health Res Rev. 2007; 8(1): 29-45.

14. Bonifait L, Veillette M, Létourneau V, Grenier D, Duchaine C. Detection of Streptococcus suis in bioaerosols of swine confinement buildings. Appl Environ Microbiol. 2014; 80(11): 3296-3304.

15. Schulz J, Friese A, Klees S, Tenhagen B A, Fetsch A, Rösler U, et al. Longitudinal study of the contamination of air and of soil surfaces in the vicinity of pig barns by livestock-associated methicillin-resistant Staphylococcus aureus. Appl Environ Microbiol. 2012; 78(16): 56665671.

16. Hamscher G, Pawelzick H T, Sczesny S, Nau H, Hartung J. Antibiotics in dust originating from a pig-fattening farm: A new source of health hazard for farmers? Environ Health Perspect. 2003; 111(13): 1590-1594.

17. Philippe F X, Cabaraux J F, Nicks B. Ammonia emissions from pig houses: Influencing factors and mitigation techniques. Agric Ecosyst Environ. 2011; 141(3-4): 245-260.

18. Anonym. Verordnung zum Schutz landwirtschaftlicher Nutztiere und anderer zur Erzeugung tierischer Produkte gehaltener Tiere bei ihrer Haltung (Tierschutz-Nutztierhaltungsverordnung - TierSchNutztV). Federal Ministry of Justice and Consumer Protection http://www. gesetze-im-internet.de/tierschnutztv/BJNR275800001.html (access: 2015.10.02).

19. Hamilton T D C, Roe J M, Webster A J F. Synergistic role of gaseous ammonia in etiology of Pasteurella multocida-induced atrophic rhinitis in swine. J Clin Microbiol. 1996; 34(9): 2185-2190.

20. Jones J B, Burgess L R, Webster A J F, Wathes C M. Behavioural responses of pigs to atmospheric ammonia in a chronic choice test. Anim Sci. 1996; 63(3): 437-445.

21. Takai H, Nekomoto K, Dahl P J, Okamoto E, Morita S, Hoshiba S. Ammonia contents and desorption from dusts collected in livestock buildings. Agric Eng Int CIGR J Sci Res Dev. 2002; 4 (Manuscript BC 01 005): 1-11.

22. Hamon L, Lagadec S, Dumont E, Landrain B, Landrain P, Andrès Y. Quantification of the NH3 adsorption on dusts and its consequences on the design of systems for the removal of aerial pollutants in piggeries. Proceedings of the 9th International Livestock Environment Symposium; 2012 Jul 8-12; Valencia, Spain. New York: Curran Associates; 2013.

23. Takai H, Moller F, Iversen M, Jorsal SE, Bille-Hansen V. Dust control in pig houses by spraying rapeseed oil. Transact ASAE. 1995; 38(5): 1513-1518.

24. Dunowska M, Morley P S, Hyatt D R. The effect of Virkon ${ }^{\star}$ S fogging on survival of Salmonella enterica and Staphylococcus aureus on surfaces in a veterinary teaching hospital. Vet Microbiol. 2005; 105(3-4): 281-289.

25. Taneja N, Biswal M, Kumar A, Edwin A, Sunita T, Emmanuel R, et al. Hydrogen peroxide vapour for decontaminating air-conditioning ducts and rooms of an emergency complex in northern India: time to move on. J Hosp Infect. 2011; 78(3): 200-203.
26. Vardar C, Ilhan K, Karabulut O A. The application of various disinfectants by fogging for decreasing postharvest diseases of strawberry. Postharvest Biol Technol. 2012; 66: 30-34.

27. Costa A, Colosio C, Gusmara C, Sala V, Guarino M. Effects of disinfectant fogging procedure on dust, ammonia concentration, aerobic bacteria and fungal spores in a farrowing-weaning room. Ann Agric Environ Med. 2014; 21(3): 494-499.

28. Schulz J, Bao E, Clauss M, Hartung J. The potential of a new air cleaner to reduce airborne microorganisms in pig house air: preliminary results. Berl Munch Tierarztl Wochenschr. 2013; 126(3-4): 143-148.

29. Friese A, Schulz J, Hoehle L, Fetsch A, Tenhagen BA, Hartung J, et al. Occurrence of MRSA in air and housing environment of pig barns. Vet Microbiol. 2012; 158(1-2): 129-135.

30. Huneau-Salaün A, Michel V, Balaine L, Petetin I, Eono F, Ecobichon F, et al. Evaluation of common cleaning and disinfection programmes in battery cage and on-floor layer houses in France. Br Poult Sci 2010; 51(2): 204-212.

31. Anonym. Bijlage IV: Uitvoering van het hygiënogram. Federaal Agentschap voor de veiligheid van de voedselketen and Agence fédérale pour la sécurité de la chaîne alimentaire http://www.favvafsca.be/dierengezondheid/salmonella/_documents/2011_11_14_ BijlageIVbijomzendbriefGQNL20111007.pdf (access: 2016.05.03).

32. Nathues H, Spergser J, Rosengarten R, Kreienbrock L, Grosse Beilage E.Value of the clinical examination in diagnosing enzootic pneumonia in fattening pigs. Vet J. 2012; 193(2): 443-447.

33. Madec F, Kobisch M. Bilan lésionnel des poumons de porcs charcutiers à l'abattoir. J Rech Porc Fr. 1982; 14: 405-412.

34. Haeussermann A, Vranken E, Aerts J M, Hartung E, Jungbluth T, Berckmans D. Evaluation of control strategies for fogging systems in pig facilities. Transact ASAE. 2007; 50(1): 265-274.

35. Ni J Q, Hendriks J, Coenegrachts J, Vinckier C. Production of carbon dioxide in a fattening pig house under field conditions. I. Exhalation by pigs. Atmos Environ. 1999; 33(22): 3691-3696.

36. Kanitz E, Otten W, Tuchscherer M. Central and peripheral effects of repeated noise stress on hypothalamic-pituitary-adrenocortical axis in pigs. Livest Prod Sci. 2005; 94(3): 213-224.

37. Saleh M. Air quality in different housing systems for poultry with special reference to dust and airborne micro organisms. PhD- Thesis. Hannover (DE), Tierärztliche Hochschule Hannover, 2006.

38. Lai H T L, Aarnink A J A, Cambra-López M, Huynh T T T, Parmentier H K, Groot Koerkamp P W G. Size distribution of airborne particles in animal houses. Agric Eng Int: CIGR J. 2014; 16(3): 28-42.

39. Agarwal R, Gupta D.Severe asthma and fungi: current evidence. Med Mycol. 2011; 49(Suppl 1): 150-157.

40. Ivanov I E. Treatment of broiler litter with organic acids. Res Vet Sci. 2001; 70(2): 169-173.

41. Fujimura M, Kamio Y, Myou S, Hashimoto T. Effect of oral mexiletine on the cough response to capsaicin and tartaric acid. Thorax. 2000; 55(2): 126-128.

42. Moreaux B, Beerens D, Gustin P. Development of a cough induction test in pigs: effects of SR 48968 and enalapril. J Vet Pharmacol Ther. 1999; 22(6): 387-389. 